\title{
PROTEIN REQUIREMENTS OF OLDER INDIVIDUALS
}

\author{
D. JOE MILLWARD ${ }^{1}$ AND SUSAN B. ROBERTS
}

${ }^{1}$ Centre for Nutrition and Food Safety, School of Biological Sciences, University of Surrey, Guildford, Surrey GU2 5XH, UK

${ }^{2}$ The Jean Mayer USDA Human Nutrition Research Center on Aging at Tufts

University, 711 Washington Street, Boston, MA 02111, USA

\section{CONTENTS}

INTRODUCTION . . . . . . . . . . . . . . . . . . . 67

METHODOLOGICAL ISSUES CONCERNING THE MEASUREMENT OF

NITROGEN BALANCE . . . . . . . . . . . . . . . 68

PROPAGATION OF ERRORS .

EFFECTS OF ENERGY BALANCE ON NITROGEN BALANCE • . . . . 69

ASSESSMENT OF ALL LOSSES. . . . . . . . . . . . . . . . 70

IMPLICATIONS OF SARCOPENIA FOR NITROGEN BALANCE STUdiES . . 71

EFFECT OF STUDY DURATION ON NITROGEN BALANCE . . . . . . 72

Day-to-day variations . . . . . . . . . . . . . . . . . . 72

Adaptation . . . . . . . . . . . . . . . . . . 72

SUMMARY OF EXPECTED BIAS IN THE NITROGEN BALANCE METHOD IN
OLDER SUBJECTS . . . . . . . . . 74

ISSUES CONCERNING THE INTERPRETATION OF NITROGEN

BALANCE STUDIES . . . . . . . . . . . . . 74

INFLUENCE OF EXPERIMENTAL DESIGN ON MEASURED REQUIREMENT
VALUES.

EVIDENCE FOR DIFFERENCES IN THE REQUIREMENT VALUES BETWEEN
YOUNG AND ELDERLY

SUMMARY OF NITROGEN BALANCE STUDIES WITH OLDER
INDIVIDUALS

IMPLICATIONS FOR PROTEIN REQUIREMENTS FROM POPULATION

SUMMARY OF PROTEIN REQUIREMENTS IN OLDER INDIVIDUALS

AND RECOMMENDATIONS FOR FUTURE RESEARCH . . . . . 83

REFERENCES . . . . . . . . . . . . . . . . . 85

\section{INTRODUCTION}

The $1985 \mathrm{FAO} / \mathrm{WHO} / \mathrm{UNU}$ Expert Consultation concluded that healthy elderly people have a dietary protein requirement that is not less than the need established for younger adults, i.e. a mean protein requirement of $0.6 \mathrm{~g} / \mathrm{kg}$ good quality protein, with a safe protein intake (to reflect individual variability in requirements) of $0.75 \mathrm{~g} / \mathrm{kg}$. They commented "This figure is higher than that for younger adults in relation to lean body mass" 
(recognizing the reduced amount of lean tissue in this group), "because it is an accepted fact that protein utilisation is less efficient in the elderly." This conclusion has been widely adopted by national committees in the US (NRC, 1989) and UK (Department of Health, 1991).

In fact the 1985 Expert Consultation had limited and conflicting information on the effects of age on protein requirements at the time the report was produced but recognized that it represents an important practical issue requiring resolution. It had been shown that young and elderly subjects exhibited similar responses to a low protein diet in terms of the fall in urinary nitrogen losses (Rand et al. 1976) and the extent of obligatory $\mathrm{N}$ losses per $\mathrm{kg}$ body weight (Scrimshaw et al. 1976), but few multipoint balance studies had been published. Furthermore, while relatively little additional information has been published since the 1985 report, a recent reassessment of the published data in the context of a new $\mathrm{N}$ balance study has concluded that the protein rquirements of the elderly should be increased to $1-1.25 \mathrm{~g} / \mathrm{kg}$ daily (Campbell et al. 1994; Campbell \& Evans, 1996). However, the interpretation of $\mathrm{N}$ balance data is especially difficult in the case of the elderly, not least because there are more constraints over experimental design than with studies on younger subjects. Consequently any revision of the 1985 recommendations should only be made on the basis of a thorough evaluation of all pertinent information. What follows therefore is a re-examination of published data pertinent to the issue of protein requirement of older subjects with a view to examining the question, is there a case for any revision of the 1985 recommendation of no change in protein requirements with ageing (expressed as $\mathrm{g} / \mathrm{kg}$ body weight)? We look critically at the methodology of assessment of protein requirements especially in relation to specific considerations which relate to the elderly. We have also examined additional studies which could provide support for any change in current recommendations.

\section{METHODOLOGICAL ISSUES CONCERNING THE MEASUREMENT OF NITROGEN BALANCE}

Current recommendations on minimum protein needs in adult subjects are based on the results of $\mathrm{N}$ balance experiments. The general limitations of the $\mathrm{N}$ balance method are well known (see Rand et al. 1981; Millward et al. 1989; Crim \& Munro, 1994). However, we believe that recent experimental designs in balance trials with the elderly raise important issues relating to currently accepted design and analysis of balance trials for any age which require re-examination. It is certainly necessary to examine the potential weaknesses of the $\mathrm{N}$ balance method as it is applied to older individuals before evaluating the data it yields. We are not aware of any detailed discussion of the utility of the method for determining changes in protein requirements with ageing.

\section{PROPAGATION OF ERRORS}

A general concern over the $\mathrm{N}$ balance method, applying to subjects of all ages, is that measurements of $\mathrm{N}$ balance are relatively imprecise. $\mathrm{N}$ balance (typically expressed as $\mathrm{mg} / \mathrm{kg}$ body weight per day) is determined as the difference between dietary $\mathrm{N}$ intake and $\mathrm{N}$ losses, where $\mathrm{N}$ losses are the sum of $\mathrm{N}$ excretion in urine and faeces and $\mathrm{N}$ losses from other 'miscellaneous' routes (mainly sweat, with skin, hair, breath ammonia, nail clippings, and so forth; see Zanni et al. 1979; FAO/WHO/UNU, 1985). In subjects consuming diets containing expected $\mathrm{N}$ requirements, $\mathrm{N}$ intake and $\mathrm{N}$ excretion are very large in relation to $\mathrm{N}$ balance and this inevitably leads to considerable error in the prediction of $\mathrm{N}$ balance in 
Table 1. Precision of nitrogen balance calculated by error propagation from anticipated error in measurement of nitrogen intake and nitrogen losses

\begin{tabular}{|c|c|c|}
\hline Typical values & $\begin{array}{c}\text { Amount } \\
(\mathrm{mg})\end{array}$ & Expected error \\
\hline $\mathrm{N}$ intake & 10000 & $2 \% \mathrm{Cv}$ (conservative) - \pm 200 \\
\hline$N$ losses & & \\
\hline Urine & 8440 & \\
\hline Faeces & 1000 & $3 \% \mathrm{CV}$ (conservative) \pm 300 \\
\hline Miscellaneous & 560 & \\
\hline $\mathrm{N}$ balance & 0 & $\pm 360^{\mathrm{al}}\left( \pm 5 \cdot 5^{\mathrm{b}} \mathrm{mg} / \mathrm{kg}\right.$ per $\left.\mathrm{d}\right)$ \\
\hline
\end{tabular}

a Calculated by error propagation.

"Assumes $65 \mathrm{~kg}$ body weight.

individual subjects. Table 1 illustrates typical values for each component of the balance equation. Even if the coefficients of variation (CV) for measurements of $N$ intake and the sum of $\mathrm{N}$ excretions are taken as only 2 and $3 \%$ respectively (conservative values taking into account only the precision of the $\mathrm{N}$ analysis and assuming minimal error associated with both provision and measurement of $\mathrm{N}$ intake and collection and recovery of urinary/faecal losses), standard calculations of error propagation demonstrate that the SD for the measurement of $\mathrm{N}$ balance is at least $360 \mathrm{mg} / \mathrm{d} \mathrm{N}(5.5 \mathrm{mg} / \mathrm{kg}$ body weight daily). Thus, for an individual subject who is exactly in $\mathrm{N}$ balance, the measured $\mathrm{N}$ balance will typically be in the range -11 to $+11 \mathrm{mg} / \mathrm{kg}$ daily (i.e. $\pm 2 \mathrm{sD}$ ). From this observation it must be concluded (1) that relatively little weight should be given to individual values for $\mathrm{N}$ balance unless they are substantially different from zero, and (2) that group mean values should be the primary data used to assess $\mathbf{N}$ balance. A corollary of these suggestions is that the finding that half of a group of subjects were in negative $\mathrm{N}$ balance and the other half in positive balance should not generally be taken to indicate that the level of dietary $\mathrm{N}$ is inadequate for half of the subjects, because between-subject differences can usually be attributed to methodological error.

In addition to this random error there may be a systematic error, at least at high intakes. Hegsted (1976), in discussing data indicating an apparent overestimation of $\mathrm{N}$ balance at high intake levels, argued that with the likelihood of an overestimate of intake (subjects not eating all food provided) and underestimate of losses (subjects not collecting all losses), there will be a bias towards overestimate of $\mathrm{N}$ balance. Clearly the magnitude of this error cannot easily be predicted, so that it is by no means clear that such a bias does account for the observed positive balance at high intakes. In any case the studies of Pannemans $e t$ al. $(1995 a, b)$ suggest that this phenomenon of unrealistic positive balance at high intakes is much less marked in the elderly $(11 \mathrm{mg} \mathrm{N} / \mathrm{kg})$ than in young adults fed the same high protein diet $(47 \mathrm{mg} \mathrm{N} / \mathrm{kg})$.

\section{EFFECTS OF ENERGY BALANCE ON NITROGEN BALANCE}

The choice of energy intake consumed by subjects undergoing $\mathrm{N}$ balance trials represents a major concern of the $\mathrm{N}$ balance method, applying to studies on subjects of all ages. The long recognized influence of energy balance on $\mathrm{N}$ balance (e.g. Calloway \& Spector, 1954), which various attempts have been made to quantify (Calloway, 1981; Pellett \& Young, 1992), poses both practical and theoretical problems. The practical problem relates to the need for nitrogen balance studies to be conducted in individuals in energy balance. Given the positive influence of energy intake on $\mathbf{N}$ balance, if energy requirements are 
underestimated then protein requirements will be overestimated, and vice versa. In fact, energy requirements of the elderly may have been underestimated in past $\mathrm{N}$ balance studies if the energy levels provided were based on recommendations of the $1985 \mathrm{FAO} /$ WHO/UNU report. This report suggested that energy requirements may be 1.51 times basal metabolic rate (BMR), which may be too low for many healthy elderly subjects unless they are very sedentary. Energy requirements are now expressed in terms of estimated rates of energy expenditure which are described in terms of BMR times the physical activity level (PAL). The PAL value varies according to occupation and lifestyle which influence physical activity and the major component of energy expenditure above the BMR. Recent measurements indicate PAL values of 1.68 (Roberts, 1996), so were energy needs to be based on the FAO guidelines they would have been underestimated by $10 \%$. In fact actual intakes adopted in some studies are reported to be much lower than this (e.g. only 1.33 times BMR; Uauy et al. 1978), a potential underestimate of $21 \%$. According to Pellett \& Young (1992) the multiple regression of $N$ balance (NB) on energy (EI) and $N$ (NI) intakes is $\mathrm{NB}=0 \cdot 171 \mathrm{NI}+1 \cdot 006 \mathrm{EI}-69 \cdot 13$, i.e. an energy intake-N balance equivalence of $1 \mathrm{mg} \mathrm{N} / \mathrm{kg}$ gain per extra $1 \mathrm{kcal} / \mathrm{kg}$ intake. Underestimates of energy intakes in this range $(10-21 \%)$ would result in negative balances of between 3.5 and $7.5 \mathrm{mg} \mathrm{N}$ per $\mathrm{kg}$ if these equations are valid. The data set analysed by Pellett \& Young (1992) was limited to only those balance studies where energy intake was a variable and did not include many multilevel trials at one energy level. Furthermore the slope of the energy balance- $\mathrm{N}$ balance relationship in the overall data set may overestimate the effect somewhat since it appears to be influenced by a small number of very low and very high energy intakes associated with low and high $\mathrm{N}$ balances (Pellett \& Young, 1992), a common problem with linear regression analytical models. This may be why their equation predicts an unrealistic energy requirement for the currently accepted protein requirement of $0.6 \mathrm{~g}$ protein $/ \mathrm{kg}$ or $52.4 \mathrm{kcal} / \mathrm{kg}$, a value higher than generally used and equivalent to a physical activity level of $2 \cdot 1$ for a young male of $70 \mathrm{~kg}$. Nevertheless, while the extent of the bias due to a possible underestimation of energy needs cannot be predicted with certainty in the elderly, the likely potential bias is towards overestimation of protein requirements.

There is, in any case, an unresolved conceptual problem relating to the issue of energy requirements and protein intakes. Most $\mathbf{N}$ balance studies are predicated on the view that energy and protein requirements are fixed and can be separately defined at least in terms of minimal values. Thus in examining long term $\mathrm{N}$ balance studies showing that additional energy intake was needed to restore $\mathrm{N}$ balance and lower plasma transaminases in subjects fed $0.57 \mathrm{~g} / \mathrm{kg}$ (Garza et al. 1976), the authors argue from conventional wisdom that the protein intake was inadequate. In fact it is equally logical to argue that energy requirements vary according to the dietary protein level, especially at low protein intakes, and that initially the subjects had too low an energy intake. In human studies in which measurements of actual energy balance can only be made very approximately with imprecise measurements of body energy and compositional change, monitoring the consequences of variable energy or $\mathrm{N}$ balance is difficult and the extent to which changes in body weight accurately reflect changes in lean body mass is very difficult to assess. There is abundant animal evidence for positive $\mathrm{N}$ balance in animals losing weight and in negative energy balance and vice versa (e.g. Coyer et al. 1987).

\section{ASSESSMENT OF ALL LOSSES}

Many investigators are able to measure only urinary and faecal losses and assume a figure for any other surface or secreted losses. FAO/WHO/UNU (1985) suggested that all such miscellaneous $\mathrm{N}$ losses should be taken as $8 \mathrm{mg} / \mathrm{kg}$ in adults, an increase from the value of 
$5 \mathrm{mg} / \mathrm{kg}$ that was used previously (FAO/WHO, 1973). It was recognized that with the major component as $\mathrm{N}$ in sweat a variable with protein intakes, then miscellaneous losses will vary with protein intakes, degree of sweating and as a result between individuals and studies. A single figure, however, was the only practical alternative given the difficulty of measurement. The current trend is to apply a value of $8 \mathrm{mg}$ regardless of whether or not such losses have been measured. Thus in the recent re-analysis and recalculation of published data, Campbell et al. (1994) assume $8 \mathrm{mg} \mathrm{N} / \mathrm{kg}$ in all cases, even in the study of Zanni et al. (1979) in which careful measurements of losses of sweat, nails and hair indicated that elderly men lost only $2.65 \mathrm{mg} \mathrm{N} / \mathrm{kg}$ daily. In fact the origin of the value of $8 \mathrm{mg}$ is not entirely clear. The values listed in the 1985 report are equivalent on average to $6 \mathrm{mg}$ for men and $6.6 \mathrm{mg}$ for women, so 8 represents a margin for error.

In any case the published values include limited information on older subjects, mainly the data of Zanni et al. (1979). For some components of the miscellaneous losses, for example hair, skin and nails, a fall with age might be predicted, although measurements on young (Calloway et al. 1971) and older (Zanni et al. 1979) subjects showed slightly higher values $(2.65$ compared with $1.85 \mathrm{mg} / \mathrm{kg})$. However, most of the losses are urea in sweat $(80 \%$ in the studies of Zanni et al. 1979), and this varies markedly not only with the level of exercise but also with clothing. Thus sweat $\mathrm{N}$ losses were higher in elderly men with heavy underclothing than in younger men. Since blood urea levels vary with protein intake over more than a 2 -fold range between intakes of 0.35 and $1.5 \mathrm{~g}$ protein $/ \mathrm{kg}$ (e.g. Price et al. 1994) then miscellaneous losses at fixed sweating rates should vary with protein intake, and this is found (Calloway et al. 1971). Egun \& Atinmo (1993) reported skin sweating losses of 5.5, $6.4,6.6$ and $7.1 \mathrm{mg} \mathrm{N} / \mathrm{kg}$ in Nigerian women fed protein intakes of $0.3,0.4,0.5$ and $0.6 \mathrm{~g}$ protein $/ \mathrm{kg}$, losses much higher than in most other published studies. The authors assumed that this reflected increased sweat losses in tropical climates. Clearly few laboratories have the expertise and experience to measure such losses so that a value will have to be assumed. However the effect of applying values of $8 \mathrm{mg} \mathrm{N}$ to studies in adapted individuals at low protein intakes may be to underestimate balance by as much as $4-5 \mathrm{mg} \mathrm{N} / \mathrm{kg}$.

\section{IMPLICATIONS OF SARCOPENIA FOR NITROGEN BALANCE STUDIES}

Older individuals exhibit a gradual loss of lean body mass with age (Cohn et al. 1980) which has been named sarcopenia (Rosenberg, 1989). This raises the question of whether it is appropriate to require older individuals to be in zero $\mathrm{N}$ balance during $\mathrm{N}$ balance studies. A corollary of this is that any observed negative $\mathrm{N}$ balance in an older subject which is attributed to inadequate dietary protein intake may be more correctly due to an inevitable loss of $\mathrm{N}$ associated with ageing. The mechanism of sarcopenia is unknown but may be due to some extent to declining physical activity since strength (resistance) training can retard its progress (Evans \& Campbell, 1993). Although the rate of loss of body nitrogen with age is not known with any accuracy, an estimate can be made from the measurements of Cohn et al. (1980). Assuming a loss of $0.35 \mathrm{~kg} /$ year of muscle (20\% wet weight protein), $\mathrm{N}$ losses in older individuals would amount to about $35 \mathrm{mg} / \mathrm{d}(0.5 \mathrm{mg} / \mathrm{kg})$. Clearly on the basis of the above this rate of loss would be undetectable by $\mathrm{N}$ balance studies and would only become a significant factor if the loss were 10 times this rate. 


\section{EFFECT OF STUDY DURATION ON NITROGEN BALANCE}

Day-to-day variations

Day-to-day variations in the $\mathrm{N}$ excretion of individuals on constant intake of $\mathrm{N}$ are observed (Sukhatme \& Margen, 1978; Rand et al. 1985). Within a study of similar subjects fed the same diets, the interindividual $\mathrm{CV}$ of urinary $\mathrm{N}$ excretion on one diet may be $36 \%$, and attempts to assess requirements (from zero balance intercepts) may result in $\mathrm{CV}$ of up to $50 \%$ (Rand et al. 1981). This means that collection periods of a minimum of $5 \mathrm{~d}$ are recommended (UNU/WHP, 1979). Clearly the reason for this day-to-day variation is a combination of errors and true variation in daily balance as a result of lack of precision in the way any biological controller of protein and amino acid balance operates (see Millward, 1995). One potential error not usually considered in short term balances is variation in clearance of the urea pool which influences daily balance. In the past this has been considered as a confounding factor only in very short term measurements (e.g. $<1 \mathrm{~d}$, Price et al. 1994). However, calculations of changes in the urea pool based on plasma urea concentrations measured over $48 \mathrm{~h}$ periods identified changes in individual subjects equivalent to up to $14 \mathrm{mg}$ urea- $\mathrm{N} / \mathrm{kg}$ daily, which were of unexplainable and unpredictable size and direction (Price, 1991). Because of this, studies examining $\mathbf{N}$ balance based on $2 \mathrm{~d}$ urine collection periods (e.g. Pannemans et al. 1995a, b) must be viewed with great caution. This is another reason why group mean values should be the primary data used to assess $\mathrm{N}$ balance (the approach adopted by Pannemans et al. 1995a,b).

\section{Adaptation}

The time dependency of adaptive mechanisms of protein and amino acid metabolism which regulate balance is especially problematic. The protein intakes of free-living individuals in industrialized nations are typically 1.5-2.0 times higher than the currently recommended minimum protein needs and all balance studies require trials of intakes below habitual levels, so adaptation to these low intakes needs to be considered. As pointed out previously (Millward et al. 1989), the shape of the $\mathrm{N}$ balance curve and the apparent requirement vary significantly with the sequence of intake levels and consequent length of the initial adaptive period. Subjects given a low intake of beef protein $(55 \mathrm{mg} \mathrm{N} / \mathrm{kg}$ daily) achieved a more positive $\mathrm{N}$ balance when the low intake was approached with gradual reductions (descending series) compared with the more abrupt change from usual intakes to the low intake (ascending series, Atinmo et al. 1988). Thus, compared with the latter design, the former descending series allows more time for adaptation to low levels of intake. Many sequential studies have involved randomization of the dietary changes to allow for these effects which would remove any systematic error in the consequent balance curve, although it will of course contribute to the large interindividual variation.

While all accept the need to equilibrate subjects on a reduced protein diet before minimum protein requirements can be established, there are differences of opinion on the way in which this should be and is done in practice, and these differences markedly influence outcome.

Early studies indicated that an equilibration period of $5 \mathrm{~d}$ would suffice and this time period has been recommended for multilevel balance studies with a $1 \mathrm{~d}$ protein free period to facilitate adaptation (UNU/WHP, 1979). However, there is ample evidence of adaptations continuing much beyond $5 \mathrm{~d}$. Studies of $\mathrm{N}$ excretion aimed at establishing the magnitude of the obligatory $\mathrm{N}$ losses in subjects fed a protein free diet showed that urinary losses fell continuously over $7 \mathrm{~d}$, reaching a stable output between 7 and $14 \mathrm{~d}$ (Scrimshaw et al. 1972). In our own studies normal adult subjects on a high protein diet ( $2 \mathrm{~g} / \mathrm{kg}$ daily) given the current recommended $\mathrm{N}$ intake of $0.75 \mathrm{~g} / \mathrm{kg}$ daily took more than $14 \mathrm{~d}$ to reduce 
Table 2. Effect of study duration on mean nitrogen balance when nitrogen intake is constant

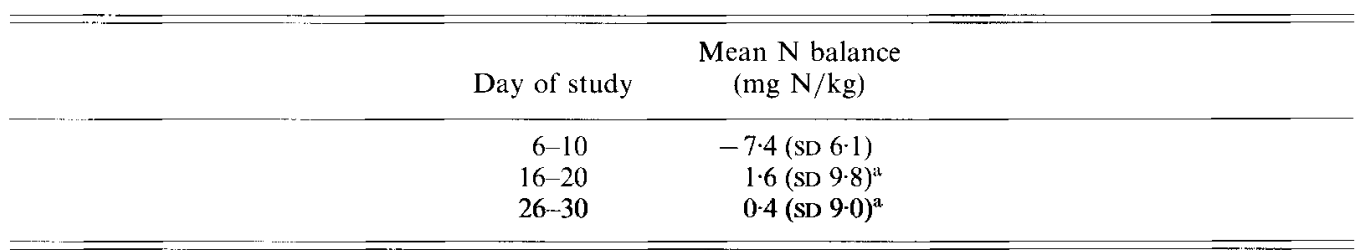

Data from Gersovitz et al. (1982) for young men receiving $0.8 \mathrm{~g} / \mathrm{kg}$ protein for $30 \mathrm{~d}$.

a Significantly different from values for days 6-10.

their urinary losses and $\left[{ }^{13} \mathrm{C}\right]$ leucine oxidation rates sufficiently to achieve balance at the lower level (Quevedo et al. 1994). Long term $\mathrm{N}$ balances on very low intakes $(0.36 \mathrm{~g}$ protein $/ \mathrm{kg})$ which led to initial losses of lean tissue showed continuing adaptation over $77 \mathrm{~d}$ in that six out of nine subjects achieved balance even at this very low level (Durkin: see Durkin et al. 1984; FAO/WHO/UNU, 1985, table 17).

Whether there is a delayed equilibration in older subjects due to a slower rate of protein turnover is not known but it is clear that long term adaptation occurs in this group. Thus a $30 \mathrm{~d}$ study with constant protein $(0.8 \mathrm{~g} / \mathrm{kg})$ and energy intake in older men showed that equilibrium was not reached after $5 \mathrm{~d}$ (Gersovitz et al. 1982). As shown in Table 2, the mean $\mathrm{N}$ balance of the study group changed from $-7.4 \mathrm{mg} / \mathrm{kg}$ to $+0.4 \mathrm{mg} / \mathrm{kg}$ over the $30 \mathrm{~d}$ study. Casteneda et al. (1995) fed a marginal protein intake $(0.45 \mathrm{~g})$ to six elderly women (66-79 years) for 9 weeks. The negative $\mathrm{N}$ balance during week 3 (group mean $=$ $-15.3 \pm 3.3 \mathrm{mg} \mathrm{N} / \mathrm{kg}$ daily) shifted towards $\mathrm{N}$ equilibrium at week 9 (group mean $=$ $-5 \cdot 2 \pm 1 \cdot 3 \mathrm{mg} \mathrm{N} / \mathrm{kg}$ daily).

Clearly, feeding a low or even protein free diet prior to test intakes will allow adaptive reductions in amino acid oxidation rates and the consequent metabolic demand for protein. However, this induces an additional problem in that tissue protein will be lost during this regimen and this will influence the utilization of protein and balance achieved in subsequent diet periods. The tissue loss was demonstrated by Castaneda et al. (1995), showing that subjects fed a marginal protein intake in negative $\mathrm{N}$ balance exhibited an $8 \%$ decline in muscle mass (assessed by ${ }^{40} \mathrm{~K}$ and urinary creatinine). Thus where very low protein intakes or protein free intakes are given to allow adaptation from high habitual intakes, ideally time should also be allowed during subsequent submaintenance balance periods to enable tissue protein repletion. Until repletion has occurred and the appropriate regulated level of body protein is restored (see Millward, 1995) protein utilization is likely to be more efficient with a more positive balance. In practice no studies run for sufficient time to allow such complete adaptation. This may account for the much lower requirement values reported by Zanni et al. (1979) in elderly subjects. These were studies on elderly men (63-77) given two levels of egg protein intake $(0.38$ and $0.45 \mathrm{~g} / \mathrm{kg}$, with energy at $31 \mathrm{kcal} / \mathrm{kg}$ providing 1.61 times BMR) after $17 \mathrm{~d}$ on a protein free diet prior to the two $15 \mathrm{~d}$ test periods. Since they were either in negative balance or in very slight positive balance during these two feeding trials, the tissue protein lost during the initial period could not have been repleted during the subsequent dietary balance periods. Although measured losses of body weight were reported to be minimal, it is not possible to maintain body protein on a protein free diet. It can be assumed therefore that there was a greater than usual efficiency of utilization and overestimation of $\mathrm{N}$ balance in these studies.

The implication of the above is that as most subjects will enter studies at intakes well above minimum requirements the requirement intake determined in feeding trials will 
either overestimate minimum needs if insufficient time is allowed for adaptation or underestimate needs if the initial adaptive period allows substantial loss of tissue protein. In practice, studies of sufficient duration to allow both full adaptation of amino acid oxidation rates and repletion of any tissue lost during the adaptive period would require more time than is ever feasible. However, it does mean that more weight should be given to studies showing a low protein requirement in subjects habituated to low intakes. This was the explanation given for the finding of a mean requirement of only $0.48 \mathrm{~g}$ protein $/ \mathrm{kg}$ daily in careful balance studies in Nigerian women (Egun \& Atinmo, 1993), i.e. these women would have entered the trials in a state of long term dietary adaptation to generally lower protein intakes than those in developed countries.

\title{
SUMMARY OF EXPECTED BIAS IN THE NITROGEN BALANCE METHOD IN OLDER SUBJECTS
}

A summary of the expected direction of bias in the $\mathrm{N}$ balance method when used in older subjects is given in Table 3. Taking all the factors discussed above into account (not including problems with the estimation of energy intake, which is difficult to quantify), the combined effect is a tendency towards negative $\mathrm{N}$ balance (both true negative $\mathrm{N}$ balance and a false assumption of negative $\mathrm{N}$ balance) and thus a false overestimation of protein requirements in most studies, except for those involving depleted subjects. The magnitude of the negative bias (up to $12 \mathrm{mg} / \mathrm{kg}$ daily excluding error related to negative energy balance) is substantial in relation to mean values for measured $\mathrm{N}$ balance reported in studies designed to determine minimum protein needs, as described below.

Table 3. Summary of expected bias in nitrogen balance methodology in older subjects

\begin{tabular}{|c|c|c|}
\hline $\begin{array}{l}\text { Predicted methodological } \\
\text { problems }\end{array}$ & Direction of error & Estimated extent of bias \\
\hline Method imprecise & $\begin{array}{l}\text { No bias at normal/low intakes but } \\
\text { individual values unreliable }\end{array}$ & 0 \\
\hline $\begin{array}{l}\text { Predicted underestimation of } \\
\text { energy needs in elderly }\end{array}$ & Promotes - ve $\mathrm{N}$ balance & Negative, variable amount \\
\hline $\begin{array}{l}\text { Misc. } N \text { losses overestimated in } \\
\text { elderly? }\end{array}$ & $\begin{array}{l}\text { Promotes false prediction of }-\mathrm{ve} \\
\mathrm{N} \text { balance }\end{array}$ & Negative, $0-5 \mathrm{mg} / \mathrm{kg}$ \\
\hline $\begin{array}{l}\text { Inadequate time for adaptation } \\
\text { to lower intake }\end{array}$ & Promotes - ve $\mathrm{N}$ balance & Negative, $\geqslant 7 \mathrm{mg} / \mathrm{kg}$ \\
\hline $\begin{array}{l}\text { Balance measurement in } \\
\text { depleted subject }\end{array}$ & Promotes + ve $\mathrm{N}$ balance & Positive, variable amount \\
\hline
\end{tabular}

\section{ISSUES CONCERNING THE INTERPRETATION OF NITROGEN BALANCE STUDIES}

\author{
INFLUENCE OF EXPERIMENTAL DESIGN ON MEASURED \\ REQUIREMENT VALUES
}

Apart from issues relating to the precision and accuracy of balance at any intake, the way the requirement value is calculated from the balance data can markedly influence the outcome. An expert working group, convened to standardize protocols deployed in multicentre trials for the measurement of protein requirements in normal adults 


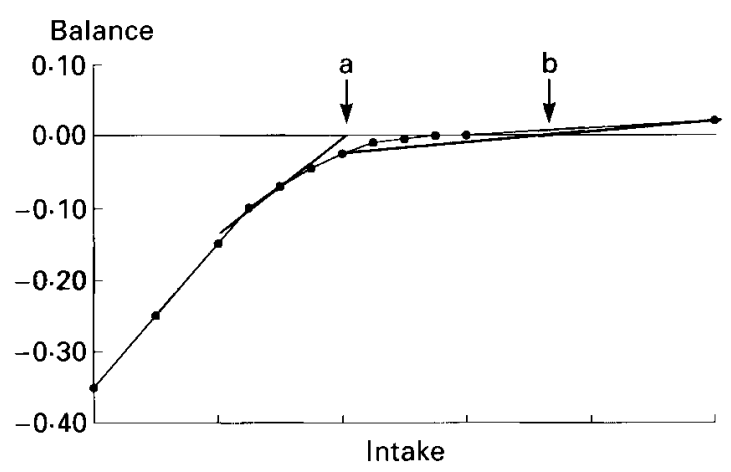

Fig. 1. Influence of choice of intakes in $\mathrm{N}$ balance studies on predicted requirement. Because the $\mathrm{N}$ balance curve is non-linear, linear regression of selected values will yield varying requirement values. Thus studies involving only submaintenance intakes will predict a lower requirement, point a, while studies involving maintenance and supramaintenance intakes will predict a high requirement, point $b$.

(UNU/WHP, 1979), recommended that in short term (10 d per intake) multilevel feeding trials, four intake levels should be given, the highest near the expected requirement, i.e. $0 \cdot 3$, $0.4,0.5$ and $0.6 \mathrm{~g} / \mathrm{kg}$ for adults. The data should then be analysed by linear regression of pooled data, accepting only individual values where a linear response of balance to intake was observed.

There are implications of this analysis for the values likely to be obtained. The $\mathrm{N}$ balance- $N$ intake curve would not be expected to be linear and it is well known that it is not, especially near to the requirement level (see FAO/WHO/UNU, 1985). Thus losses would be expected to rise to match intake as the protein-stat mechanism (Millward, 1995) limits protein gain above the regulated level, and there is abundant evidence for this theoretically expected asymptotic balance curve (e.g. Young et al. 1973; Atinmo et al. 1988; see Millward et al. 1989). What this means is that linear regression of just part of this balance curve will result in varying zero balance intercepts (requirement intakes) according to which intake values are chosen. If low intakes are included in the balances the slope will be steep and a low requirement will be predicted. If high intakes are included, because there is usually a positive balance (to a greater or lesser extent) there will still be a positive slope, albeit shallow, and a higher requirement will be predicted. If both very low intakes and intakes near or above the requirement level are chosen this will indicate requirement values which increase as the highest value in the feeding trials increases. This is shown schematically in Fig. 1, and is best illustrated by data recently assembled by Campbell $e t$ al. (1994) and Campbell \& Evans (1996).

These recent reports include both new data by the authors and previous data of Cheng et al. (1978), Uauy et al. (1978) and Zanni et al. (1979) recalculated by adding miscellaneous losses up to $8 \mathrm{mg} \mathrm{N} / \mathrm{d}$ (FAO/WHO/UNU, 1985) and performing linear regressions on the balance data for each individual, so that mean \pm SE values were calculated for each study. Their reassessment of the balance data of Zanni et al. (1979) is one case in point. As shown in Fig. $2 a$ the original published data included a very low protein period and two other intakes of 0.38 and $0.45 \mathrm{~g}$ protein $/ \mathrm{kg}$. Linear regressions of all the data indicated a mean requirement of $74.3 \mathrm{mg} \mathrm{N} / \mathrm{kg}(0.46 \mathrm{~g}$ protein $/ \mathrm{kg})$. Campbell et al. (1994) argued that the protein free period should not be included in the regression and, after adjusting the balances for higher miscellaneous losses which resulted in negative balances for all subjects at both intakes, re-analysed the data by individual linear regressions on the two intakes. The results are shown in Fig. $2 b$ where the line joining the two balance points is projected 


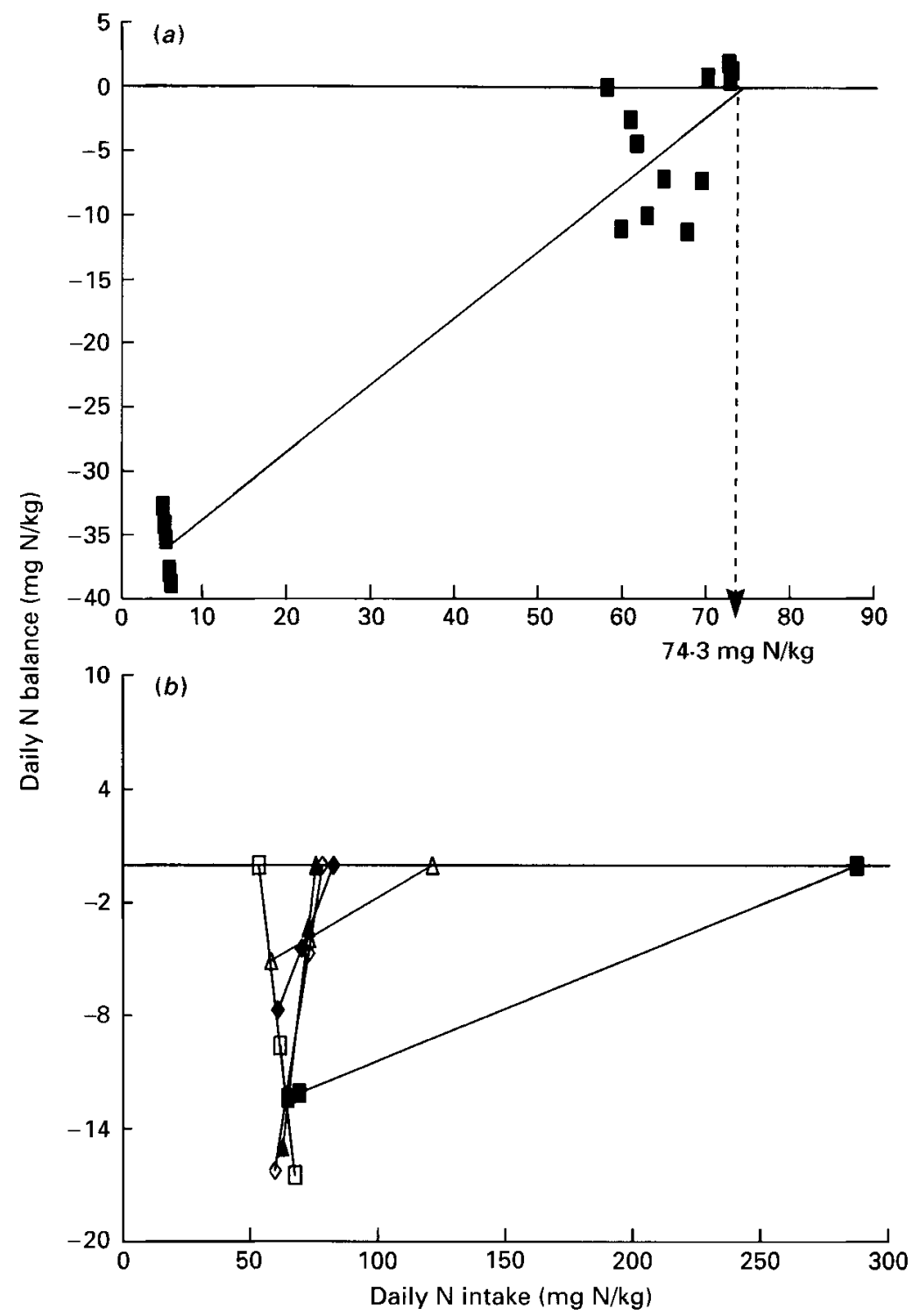

Fig. $2 a$. $\mathrm{N}$ balance data of Zanni et al. (1979) as reported and analysed by the authors. $\mathrm{N}$ balance was measured in each subject after $17 \mathrm{~d}$ on a protein free diet and on two subsequent intakes close to maintenance. Linear regression of the balances achieved by the whole group on the three intakes indicated the requirement value shown (equivalent to $0.46 \mathrm{~g}$ protein $/ \mathrm{kg}$ ). This is an example of line a in Fig. 1 .

Fig. $2 b$. N balance data of Zanni et al. (1979) as reported and analysed by Campbell et al. (1994). After removing the protein free period from the regression and adjusting the balances for higher miscellaneous losses, individual linear regressions on the two intakes indicate the lines shown projected to a zero balance intercept which indicates the requirement intake. The individual requirement values vary widely.

to a zero balance intercept. These intercepts range from intakes below the levels fed (a subject with a negative slope) to a very high intake for the subject with a very shallow positive slope. In our view this is not a sensible analysis of the data. All that can be said is that these subjects given intakes of between 0.38 and $0.45 \mathrm{~g}$ were close to balance. 


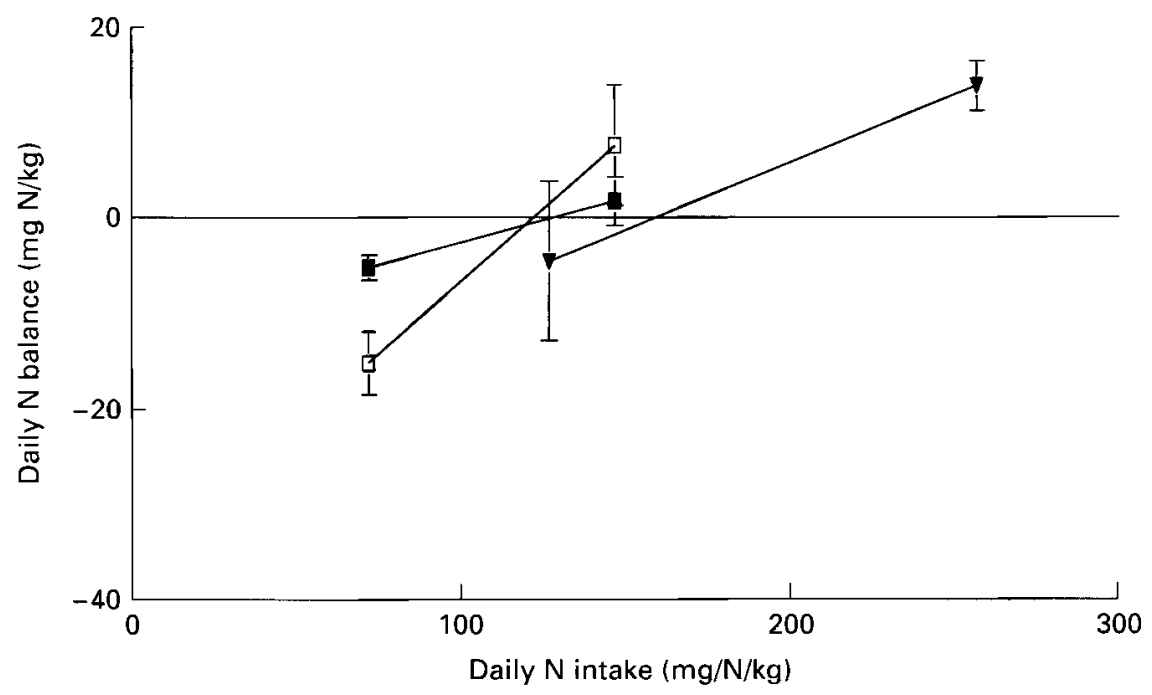

Fig. 3. N balance data reported by Campbell et al. (1994) and Castaneda $e$ t al. (1995). The two values from the study of Castaneda relate to measurements made after 3 weeks (a) and 9 weeks (b) on each intake. In each case linear regression of two values close to or above the equilibrium intake result in requirement values which increase as the highest intake increases. These are examples of line $b$ in Fig.

1. $\square$, Castaneda et al. (a); $\boldsymbol{\square}$, Castaneda et al. (b); $\boldsymbol{\nabla}$, Campbell et al.

The new data reported by Campbell et al. (1994) involved intakes of 0.8 and an excessive intake $(1.62 \mathrm{~g} / \mathrm{kg})$ and the balance data are shown in Fig. 3. At the lower intake the mean balance for the group was not significantly different from zero $(-4.6 \mathrm{SD} 8.4)$ while balance at the higher intake was positive (13.6 SD 2.6). The 'linear regression' (with just two points this is a straight line connection) indicated a zero balance intercept or 'requirement value' of $160 \mathrm{mg} \mathrm{N}, 1 \mathrm{~g}$ protein $/ \mathrm{kg}$. Given that the subjects as a group were at equilibrium at $0.8 \mathrm{~g}$ and may well have achieved equilibrium at a lower intake, the requirement value of greater than 0.8 is entirely predictable from the choice of intakes. The conclusion that the data demonstrate an increased requirement in the elderly is thus debatable.

In a second two intake level study Castaneda et al. (1995) gave either 0.45 or $0.92 \mathrm{~g}$ protein $/ \mathrm{kg}$ daily over 9 weeks to elderly women reporting $\mathrm{N}$ balances after 3 and 9 weeks on the diets. As expected, the authors found negative $\mathrm{N}$ balance, albeit lessening with time, and loss of body lean tissue on the low intake. In contrast the women given $0.92 \mathrm{~g}$ protein $/ \mathrm{kg}$ daily achieved $\mathrm{N}$ equilibrium (slightly positive) and maintained body cell mass and muscle mass throughout the study. This was interpreted as indicating a protein requirement between the two intakes. However, Campbell \& Evans (1996) reported regression analysis of data from the two intakes which indicated a daily requirement of $0.78 \mathrm{~g}$ protein $/ \mathrm{kg}$ after 3 weeks, and $0.82 \mathrm{~g}$ protein $/ \mathrm{kg}$ after 9 weeks (see Fig. 3). These values were assumed by Campbell \& Evans (1996) to demonstrate a higher protein requirement in healthy elderly subjects. In fact the zero balance intercept obtained in this way is largely predictable from the choice of the two intakes.

In reviewing this study of Castaneda et al. (1995) and other $\mathrm{N}$ balance data, Campbell \& Evans (1996) argue that because the mean requirement estimates were similar at both 3 and 9 weeks (see Fig. 3), despite the shift of $\mathrm{N}$ balance on the low intake toward equilibrium between 3 and 9 weeks, this supports the conclusion that short term balance studies are predictive of protein requirements that would be estimated from longer term studies. In fact 
it is apparent in Fig. $1 b$ that the similar 'requirement' value at 3 and 9 weeks fortuitously reflected similar moves towards equilibrium from both the negative balance at the low intake and the positive balance at the high intake. Since as discussed above the actual 'requirement' value predicted in these studies is unlikely to be an actual measure of the true minimum requirement the argument that short term balances predict long term balances can be judged to be unjustified. Campbell \& Evans (1996) also raise the important question of possible disadvantages of long term $\mathrm{N}$ balances, arguing that $\mathrm{N}$ balance data generated in such studies may not provide an accurate assessment of protein requirements of subjects in the metabolic state in which they entered the study. While this statement may be true, it is misleading. It can be argued that the metabolic demand for protein and the consequent protein requirement of individuals is largely set by the rates of amino acid oxidation induced by the particular level of habitual protein intake. Such intakes are often higher than intakes fed in balance trials, so that measurement of a minimum protein requirement for balance with complete adjustments of amino acid oxidation rates to their lowest level and with restoration of body protein mass to its appropriate level can only be achieved in long term balances on low intakes.

It is clear from the above that the intake for zero $\mathrm{N}$ balance identified in a balance trial is subject to considerable variation and uncertainty because of widely different experimental designs. Few centres appear fully to adopt the standardized protocol recommended by UNU/WHP (1979), which is unfortunate since its application does appear to yield more informative data (e.g. Egun \& Atinmo, 1993). In the past (e.g. FAO/WHO/UNU, 1985) in an attempt to draw general conclusions from the diverse range of published studies, meta-analyses have been attempted in which representative studies have been aggregated (see Millward $e t$ al. 1989) with the objective of identifying a requirement value and some measure of its variaiblity. Whilst this may be appropriate for younger adults given the large data base which exists, for the elderly with the small number of studies differing markedly in their experimental design, data aggregation in terms of selection of 'representative' studies is difficult. In fact no entirely satisfactory balance trials reporting a protein requirement for the elderly appear to have been published and certainly no published study actually conforms to the protocol identified by UNU/WHP (1979). Because of this and the unsatisfactory experimental design of most published studies (as illustrated in Fig. 2), it is unjustifiable to reach any firm conclusions over the adequacy of current protein requirement recommendations.

\section{EVIDENCE FOR DIFFERENCES IN THE REQUIREMENT VALUES BETWEEN YOUNG AND ELDERLY}

An alternative approach to attempting to identify a specific protein requirement for the elderly is to follow the arguments of Cheng et al. (1978) and search for evidence suggesting a change with age regardless of what actual values are reported. The process of definition of protein requirement for the elderly would then be definition of a value for young adults from the much larger data base, followed by identification of the magnitude of any change for older subjects. Differences in study design and analytical accuracy would be less likely to influence the outcome in this case.

In fact very few studies have compared young and old. The study of Cheng et al. (1978) involved $\mathrm{N}$ balances of elderly nursing home occupants in Chile (age 61-73) and young prisoners receiving protein intakes varying from inadequate to excessive. Both young and old subjects achieved $\mathrm{N}$ equilibrium at the same intakes $(0.8 \mathrm{~g}$ protein $/ \mathrm{kg})$ with no discernible difference between the balance curves. 
Pannemans et al. (1995a,b) mainly investigated protein turnover in elderly (Pannemans et al. (1995a) and young (Pannemans et al. (1995b) adults, but did report $\mathrm{N}$ balances on two intakes deemed as sufficient and an excess which did not differ between the two groups.

We know of no other reports which include both young and older subjects, although separate studies on young and old have been reported from the two most experienced laboratories (Berkeley and Massachusetts Institute of Technology (MIT)) so that at least analytical methods and study control can be assumed to be the same.

Zanni et al. (1979) reported the mean requirement of elderly subjects $(0.464 \mathrm{~g} / \mathrm{kg})$ to be slightly higher than the level needed by young men as studied in the same laboratory (albeit with slightly different intake levels, $0.43 \mathrm{~g} / \mathrm{kg}$; Calloway \& Margen, 1971). As discussed above, the low requirement value probably reflects the higher efficiency of utilization in these tissue depleted subjects. However, the authors concluded that "differences in the protein requirement due to age are probably quite small in the age range we have studied."

In contrast, studies reported from MIT comparing measurements on the elderly with their own previous studies on younger subjects have been equivocal as to whether there is an increased requirement in the elderly. Thus Uauy et al. (1978) reported $\mathrm{N}$ balance studies with elderly men (68-74) and women (70-84) given daily three levels $(0 \cdot 52,0.65$ and $0.8 \mathrm{~g} / \mathrm{kg}$ women; $0.57,0.70$ and $0.85 \mathrm{~g} / \mathrm{kg}$ men) of egg protein and $28-32 \mathrm{kcal} / \mathrm{kg}$ in random sequence after $1 \mathrm{~d}$ on a protein free diet. Marked differences were observed between the women and men: four out of seven women failed to achieve balance at any intake and the mean daily requirement was calculated as $0.83 \mathrm{~g}$ protein $/ \mathrm{kg}$. While this is much higher than previous multi-intake studies with young men from this laboratory $(0.44 \mathrm{~g} / \mathrm{kg}$; Young et al. 1973), the authors were uncertain about whether they did represent an increase with age. The results were less clear with the men since four out of seven achieved positive balance at all intakes with little or no slope so that a requirement value could not be calculated by individual linear regression. While the authors again concluded that the data indicated a requirement value between 0.7 and $0.85 \mathrm{~g}$ protein $/ \mathrm{kg}$, i.e. much higher than younger subjects, in fact group analysis would indicate that all levels fed were sufficient since no intake group differed significantly from zero balance.

In follow-up studies at MIT (Gersovitz et al. 1982) testing a single level of $0.8 \mathrm{~g}$ egg protein and $30 \mathrm{kcal} / \mathrm{kg}$ for $30 \mathrm{~d}$ in elderly men and women, several subjects failed to achieve or sustain balance by the end of the experimental period. It was therefore concluded that $0.8 \mathrm{~g} / \mathrm{kg}$ was either marginal or inadequate for elderly subjects. It can equally be argued that since the group mean balance data did not differ from zero after the first $10 \mathrm{~d}, 0.8 \mathrm{~g}$ was adequate for the elderly men. Furthermore, since the studies on young men which indicated a lower protein requirement involved trials at lower intake levels than those fed by either Uauy et al. (1978) or Gersovitz et al. (1982), the studies are not strictly comparable, so that taken together these MIT data cannot strictly be accepted as pointing to higher requirement values in the elderly.

\section{SUMMARY OF NITROGEN BALANCE STUDIES WITH OLDER INDIVIDUALS}

Table 4 summarizes all studies we are aware of which have investigated protein requirements in older individuals using $\mathrm{N}$ balance methods. As indicated above, all studies differ considerably in terms of their experimental design and to some extent in their stated objectives. In examining these studies we have not adjusted balances for a standardized miscellaneous loss but have accepted the authors' own assumed or measured values of the estimated average requirements. Although these differed between studies, on the basis of 


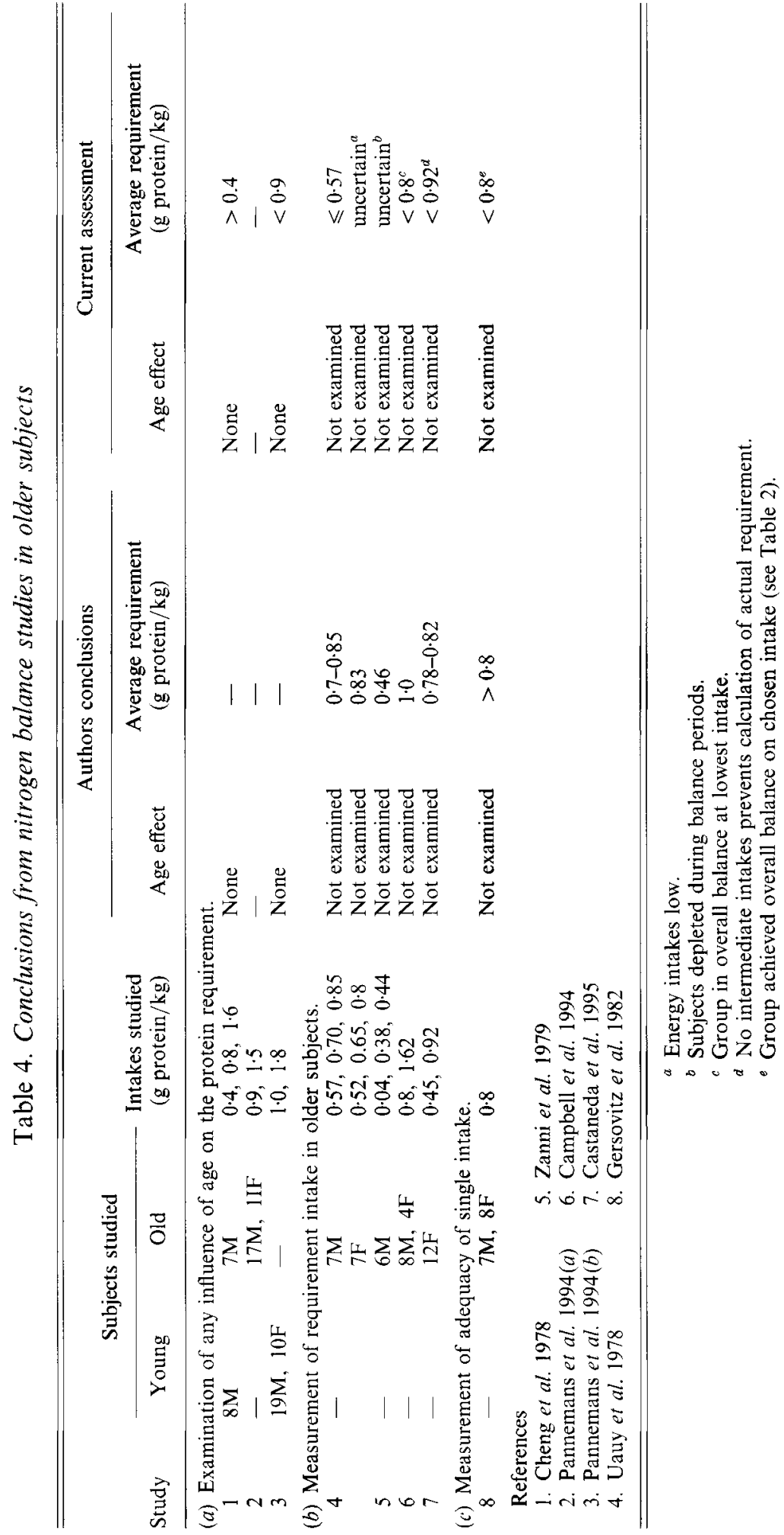


the arguments above they may have been adequate in each case with the exception of the study by Cheng et al. (1978) in which such losses were ignored. Because of the uncertainty of the data we have not listed any reference nutrient intake values (mean \pm 2 SD).

As already indicated, only two studies, Cheng et al. (1978) and Pannemans et al. $(1995 a, b)$ have addressed the question of the extent of any age-related changes in protein requirements with studies on both younger and older subjects.

Cheng et al. (1978) specifically tested the hypothesis of a change with age in protein utilization and requirement, examining balance responses in both young and elderly to a wheat-soya-milk mixture given at $0.4,0.8$ or $1.6 \mathrm{~g}$ protein and $40 \mathrm{kcal} / \mathrm{kg}$ body weight with $\mathrm{N}$ balance measured over $5 \mathrm{~d}$ at the end of an $11 \mathrm{~d}$ period, in a $0.8,0.4,1.6 \mathrm{~g}$ sequence with a $3 \mathrm{~d}$ diet break between trials. There was no difference in creatinine weight or height ratios between the two groups. Both young and old subjects achieved $\mathrm{N}$ equilibrium at intakes of $0.8 \mathrm{~g}$ protein $/ \mathrm{kg}$ with no discernible difference between the balance curves. The intakes studied do not allow a requirement value to be predicted with any confidence, even after correction for miscellaneous $\mathrm{N}$ losses (which were not included in the balance calculations), only that it is $>0.4 \mathrm{~g}$. The main uncertainty relates to the energy intakes which at $40 \mathrm{kcal} / \mathrm{kg}$ for both young and older subjects means that, for the latter group, it could have represented an excess which improved utilization and masked any deterioration. However, the actual level of energy balance in the two groups is unknown. Campbell et al. (1994) argued that recalculation to include $8 \mathrm{mg} \mathrm{N} / \mathrm{kg}$ miscellaneous losses would result in a requirement of $0.93 \mathrm{~g} / \mathrm{kg}$ which is higher than the value for young adults. In our view this reflects the higher intakes used in this study (as discussed on pp. 74-77) but more importantly the suggested adjustment does not change the authors' conclusion of no effect of age.

Pannemans et al. $(1995 \mathrm{a}, \mathrm{b})$ gave protein at 0.89 and $1.54 \mathrm{~g} / \mathrm{kg}$, i.e. 12 and $21 \%$ energy, to elderly $(63-80, n=28)$ and young $(23-35, n=29)$ men and women for 3 weeks, reporting $\mathrm{N}$ balance (urinary and faecal $+8 \mathrm{mg} \mathrm{N} / \mathrm{kg}$ miscellaneous losses) measured over 2-3 d. Mean $\mathrm{N}$ balance did not differ from zero at either intake in either age group. No agerelated differences were observed but with both intakes of potential sufficiency and the balances at the asymptote, lack of difference is hardly surprising. Although diets were fed for 3 weeks at levels aimed at energy balance, and $8 \mathrm{mg}$ miscellaneous losses were included, the balance periods were short $(2-3 \mathrm{~d})$, and there is no information on the quality of the data collection. No effects of age are indicated. Apart from demonstrating a requirement less than the levels fed $(0.89 \mathrm{~g} / \mathrm{kg})$, no specific value can be calculated from these data.

Four studies have a stated aim of identifying a requirement value in the elderly. The studies of Uauy et al. (1978) demonstrated different $\mathrm{N}$ balance responses for men and women. For the men there was little change in balance with increasing intakes so that calculation of a zero balance requirement intake from linear regression could not be performed. Because of this and the fact that the medical condition of some of the male subjects was questionable the authors concluded that the data were unsatisfactory. Nevertheless, a requirement intake of between 0.7 and $0.85 \mathrm{~g} / \mathrm{kg}$ was identified. With the men as a group in balance at all intakes we would conclude that the data show a requirement equal to or less than the lowest intake fed $(0.57 \mathrm{~g} / \mathrm{kg})$. For the women there was an improvement in balance with intake and regression indicated a mean requirement of $0.83 \mathrm{~g} / \mathrm{kg}$. In our view there is uncertainty about this conclusion because of the energy intakes, which at $27.6 \pm 6.1 \mathrm{kcal} / \mathrm{kg}$ were equivalent to intakes of only $1.23 \pm 0.25$ times the estimated BMR for elderly women of these weights over 60 years of age (Department of Health, 1991). Such intakes are grossly inadequate.

As indicated above, the design of the study reported by Zanni et al. (1979) is problematic given the chosen intakes (protein free and two similar low levels). Regression of these data 
will underestimate requirements. The design may well also overestimate protein utilization and underestimate requirements because of the depleted state of the subjects given the test intakes after the $17 \mathrm{~d}$ period on a protein free diet. While energy intakes at $31 \mathrm{kcal} / \mathrm{kg}$, which for these slightly obese subjects was 1.61 times the measured BMR, slightly less than previous studies on younger men by this group (1.65-1.7 times BMR), were adequate as judged by weight stability, even with negative $\mathrm{N}$ balance, the conclusions that the elderly can maintain balance on $0.46 \mathrm{~g}$ protein must be viewed with caution.

In the case of the studies of both Campbell et al. (1994) and Castaneda et al. (1995) we would view as currently unjustifiable their conclusions that the mean requirement is between $0.78-0.82 \mathrm{~g} / \mathrm{kg}$ (Castaneda et al. 1995) and $1.0 \mathrm{~g} / \mathrm{kg}$ (Campbell et al. 1994). In both studies the results obtained were to some extent predictable from the intakes chosen in their experimental design. Rather, what these studies do show (Fig. 3) is that the intake requirement is probably less than $0.8 \mathrm{~g} / \mathrm{kg}$, but without further studies at intermediate intakes the actual level cannot be identified.

The $30 \mathrm{~d}$ balance study aimed to test the adequacy of $0.8 \mathrm{~g} / \mathrm{kg}$ (Gersovitz et al. 1982) was interpreted as indicating a mean protein requirement $>0.8 \mathrm{~g} / \mathrm{kg}$. We would question this conclusion on the grounds that (a) since the group as a whole did not differ significantly from zero balance (see Table 2), the imprecision of the $\mathrm{N}$ balance method (described above) dictates the use of group mean values rather than individual results to derive conclusions; (b) the daily energy intakes (in $\mathrm{kcal} / \mathrm{kg}$ ) of thirty-two males and twenty-nine females are equivalent to $1 \cdot 30 \pm 0 \cdot 21$ and $1 \cdot 43 \pm 0 \cdot 21$ and may have been inadequate.

Thus, as indicated in Table 4, none of the published studies provides convincing $\mathrm{N}$ balance data indicating that protein requirements in the elderly are higher than in younger adults, currently believed to be an estimated average requirement of $0.6 \mathrm{~g} / \mathrm{kg}$.

\section{IMPLICATIONS FOR PROTEIN REQUIREMENTS FROM POPULATION STUDIES IN THE ELDERLY}

If it is assumed that only very long term consumption of marginal protein intakes is likely to allow complete adaptation and equilibration, then examination of subjects on their habitual intakes may be informative. In this case the question which might be asked is what is the evidence that variation in protein intakes towards marginal levels is detrimental in the elderly consuming self-selected diets? There are two important studies which address this issue.

Munro et al. (1987) reported on the protein nutriture of 691 men and women age 6098 years, consuming on average $1.04 \mathrm{~g} / \mathrm{kg}$, with measurements of plasma proteins and body composition including arm muscle area. Only $12-15 \%$ of subjects had protein intakes below $0.8 \mathrm{~g} / \mathrm{kg}$, which could reflect the inadequacies of the $3 \mathrm{~d}$ record measurements, but clearly overt protein deficiency was not observed. There was no evidence that lower intakes of protein in the group adversely influenced any measured parameter. On the contrary, muscle arm circumference was inversely correlated with protein intake and when a nutritional index score was calculated from albumin, triceps skin folds and transferrin levels, this was also inversely correlated, although not significantly so. Thus Munro concluded that the studies demonstrated no deleterious impact of consuming protein at the lower end of the observed range.

Bunker et al. (1987) reported actual nitrogen balances on both housebound elderly people $(n=20)$, age $70-86$ years, with mean daily protein intakes of $0.67 \mathrm{~g}$ protein $/ \mathrm{kg}$, and twenty-four healthy men and women, age 70-86, years with mean daily protein intakes of $0.97 \mathrm{~g}$ protein $/ \mathrm{kg}$. While the healthy group was in zero balance overall, the housebound 


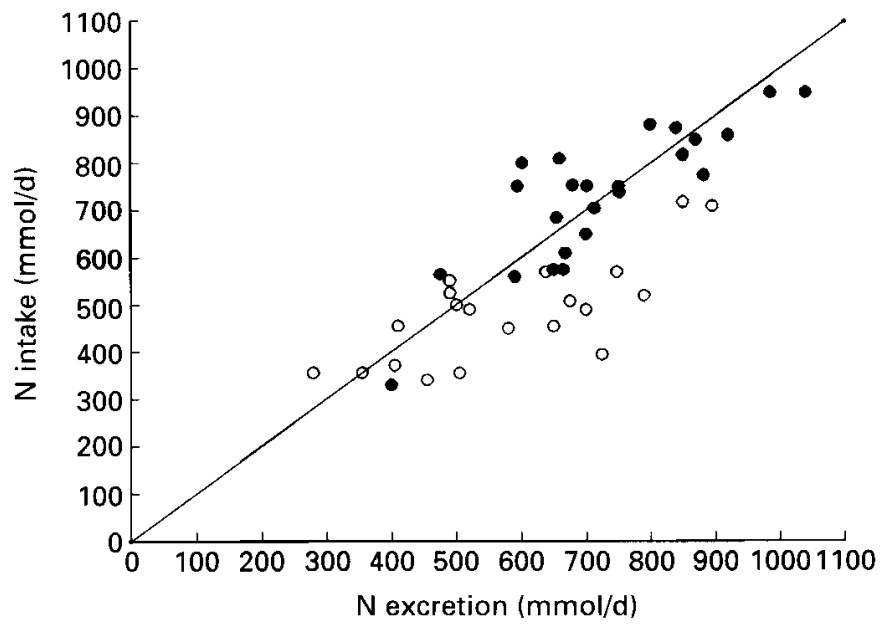

Fig. 4. Daily $N$ intake and excretion in 24 healthy $(O)$ and 20 housebound $(O)$ elderly subjects. The straight line indicates zero balance. Redrawn from Bunker et al. (1987).

group was in negative balance (see Fig. 4). However, there was no real indication that this was due to the level of protein intake since there was no correlation between protein intake and balances in either group over a wide range of intakes $(24-79 \mathrm{~g}$ protein $/ \mathrm{d}$ in the housebound and 35-92 g protein/d in the healthy group). Indeed, a subject with the lowest intake in the group $(24 \mathrm{~g} / \mathrm{d})$ was in positive balance while the subjects with the highest intake $(92 \mathrm{~g} / \mathrm{d})$ were in negative balance. Furthermore the overlapping range of intakes between the housebound and healthy groups allow comparisons to be made at the same intake. This showed that at the same intakes housebound subjects tended to be in negative balance while the healthy subjects were in positive balance. Either the immobility, illness or the lower energy intake of the housebound accounted for the negative $\mathrm{N}$ balance. Some caution must be used in assessing these data since, as with most out-patient studies which are difficult to conduct, there may have been some methodological problems given the extremely low reported energy intakes in some of the subjects. Nevertheless, taken together the data do not support any effect of protein intake on $\mathrm{N}$ balance over a range of intakes as wide as is likely to be observed in a free-living population.

While these two studies do not allow a minimum protein requirement in the elderly to be defined they do both point to free-living elderly individuals being able to adapt to protein intakes over a wide range, with no benefit in terms of either biochemical indicators or measured balance from increased intakes.

\section{SUMMARY OF PROTEIN REQUIREMENTS IN OLDER INDIVIDUALS AND RECOMMENDATIONS FOR FUTURE RESEARCH}

As described above, on the basis of our interpretation of existing research on protein needs of older individuals we find no convincing evidence for any revision of the 1985 $\mathrm{FAO} / \mathrm{WHO} / \mathrm{UNU}$ recommendations that there is no change with age in the protein requirement per $\mathrm{kg}$ body weight. Clearly, further research is needed to determine whether the intakes identified as adequate for young adults $(0.6 \mathrm{~g} / \mathrm{kg})$ are adequate for maintaining $\mathrm{N}$ balance in older individuals. 
Much has been written about the value and limitations of the $\mathrm{N}$ balance method for determination of protein requirement, with increasing references to alternative methods including tracer studies of both protein and amino acid balance and turnover (e.g. Young, 1986). While turnover data are essential if the mechanisms of body protein and amino acid balance regulation are to be fully understood, it should be noted that in principle none of these alternative tracer approaches escapes the need to measure balance per se. This is true for both nitrogen or carbon balance since without accurate intake, loss and consequent balance data, rates of protein synthesis and degradation cannot be resolved from kinetic studies of turnover. We know of no balance method which has been as rigorously evaluated as the $\mathrm{N}$ balance method. Furthermore, notwithstanding the limitations discussed above, we believe that in terms of an objective of evaluating minimum protein needs in studies over relatively short periods (i.e. weeks), the $\mathrm{N}$ balance method remains the main, if not the only, technique with the potential to produce accurate information provided that substantial efforts are made to avoid the known errors. These are those associated with energy imbalance, subject compliance, inadequate $\mathrm{N}$ equilibration, and inappropriate interpretation of the data. The fact that the technique is so time consuming and requires full subject compliance has led to short equilibration times, small numbers of subjects, and a lack of young control subjects in published $\mathrm{N}$ balanced studies - limitations that can all potentially be overcome when adequate resources and research effort are available. Moreover, improvements in the technique are now possible, because the combination of $\mathrm{N}$ balance with simultaneous measurements of energy expenditure using the doubly labelled water method will enable information to be obtained on the energy balance of the group of subjects as a whole. There is no impediment to obtaining more detailed information on the effects of ageing on miscellaneous $\mathrm{N}$ losses, and such information should help to dispel the present uncertainty over the most appropriate correction factor for use in older individuals.

Long term diet studies aimed at measuring body $\mathrm{N}$ directly are the obvious alternative to balance studies for evaluating minimum protein requirements, and while this is now feasible with several potential benefits it has yet to be exploited. Neutron activation measurements of changes in total body $\mathrm{N}$ have been used in longitudinal studies in hospital patients where rapid changes in body protein occur (e.g. Hill, 1994). With the much slower changes likely to occur in response to dietary change such studies, effectively extended $\mathrm{N}$ balance experiments, would of necessity be long term. The advantage of this admittedly expensive approach would be that the primary variable, i.e. body $\mathrm{N}$, would be measured directly and thus the potential for methodological bias would be greatly reduced. Moreover, this approach could also be used to judge the effects of intervention studies such as exercise programmes on body protein at different levels of protein intake, as well as the effects of dietary protein on related metabolic parameters.

Finally, the question must be posed as to the objective of protein requirement estimates. From a general nutritional perspective where the aim would be to satisfy the energy needs of the elderly with a natural diet of sufficient nutrient density to meet all nutrient needs, protein intakes are likely to be much higher than minimal needs. However, acceptance that knowledge of minimal protein requirements is an important research objective requires unambiguous definition of protein requirements. Waterlow (1990) and Young et al. (1987) discussed regulation of body protein in response to reduced intakes in terms of adaptation and accommodation, in which adaptation implies metabolic responses without cost while accommodation implies some cost. Examples of costs are reduced protein turnover and reduced body protein mass. Most would accept that definition of a minimal requirement is the minimum intake which allows overall body protein or $\mathrm{N}$ balance without cost. On the basis of a protein-stat mechanism of body protein regulation (Millward, 1995), in which there is a characteristic upper limit of body protein, the minimum protein requirement of 
an adult can be defined as the lowest intake which allows balance at a level of body protein which is appropriate for the subject's height and frame size. This raises the practical issue that losses of body $\mathrm{N}$ and achievement of balance at a lower body $\mathrm{N}$ level must be differentiated from any transient losses during an adaptation period which are gradually replaced, thus putting back appropriate body protein stores. This restoration stage has generally been ignored in most studies, probably because it may take a very long time.

In the case of the elderly, sarcopenia means that attainment of an optimal body protein mass may not be an appropriate end point given that there is as yet little evidence that increased protein intake can prevent this loss of muscle mass. However, what is not known at present is whether the minimum protein requirement as defined above will be optimal in relation to other aspects of long term health and well being. The epidemiology of protein intake and human health in terms of chronic disease cannot as yet be untangled from confounding lifestyle and other dietary variables (e.g. Thorogood, 1995). The studies of Munro et al. (1987), referred to above, showing inverse relationships between protein intakes and, albeit very limited, indicators of optimal protein nutriture, suggest that optimal intakes may be in the lower range of intakes of free-living relatively affluent urban populations. Indeed, the definition of a safe upper limit $(1.5 \mathrm{~g}$ or twice the reference nutrient intake of $0.75 \mathrm{~g}$ ) has resulted from such studies and other evidence, as yet very limited, of potential risks of excess protein (see Department of Health, 1991). This means that it is all the more important that minimal protein requirements of the elderly are understood. In our view the possibility that the actual biological demand for protein and amino acids in the elderly is lower than in younger adults cannot be excluded. The tendency for 'more is better' is a view which has been present within the nutritional community since debates about protein requirement started in the last century. It would be most unfortunate if it persisted into the next millennium

In conclusion, on the basis of our analysis of the limitations of the $\mathrm{N}$ balance method as applied to studies of protein requirement of older subjects we cannot identify any studies which unequivocally demonstrate either a change with age in the requirement or a mean requirement value which is higher than the values defined by FAO/WHO/UNU (1985), namely 0.6 and $0.75 \mathrm{~g} / \mathrm{kg}$ for mean and safe allowance. More research is needed to examine the effects of ageing on these parameters and to focus on the long term as well as the short term consequences of protein intake.

The authors gratefully acknowledge support from Research into Ageing, Help the Aged, the Nestlé Foundation and the United States Department of Agriculture.

\section{REFERENCES}

Atinmo, T., Mbofung, C. M. F., Egun, G. \& Osotimehin, B. (1988). Nitrogen balance study in young Nigerian adult males using four levels of protein intake. British Journal of Nutrition 60, 451-458.

Bunker, V. W., Lawson, M. S., Stansfield, M. F. \& Clayton, B. E. (1987). Nitrogen balance studies in apparently healthy elderly people and those who are housebound. British Journal of Nutrition 57, 211-221.

Calloway, D. H. (1981). Energy-protein relationships. In Protein Quality in Humans: Assessment And In Vitro Estimation, pp. 148-168 [C. E. Bodwell, J. S. Adkins and D. T. Hopkins, editors]. Westport, CT: AVI.

Calloway, D. H. \& Margen, S. E. (1971). Variation in endogenous nitrogen excretion and dietary nitrogen utilization as determinants of human protein requirement. Journal of Nutrition 101, 205-216.

Calloway, D. H., Odell, A. C. F. \& Margen, S. (1971). Sweat and miscellaneous nitrogen losses in human balance studies. Journal of Nutrition 101, 775-786.

Calloway, D. H. \& Spector, H. (1954). Nitrogen balance as related to caloric and protein intake in active young men. American Journal of Clinical Nutrition 2, 405-412.

Campbell, W. W., Crim, M. C., Dallal, G. E., Young, V. R. \& Evans, W. J. (1994). Increased protein requirements in elderly people: new data and retrospective reassessments. American Journal of Clinical Nutrition 60, 501-509.

Campbell, W. W. \& Evans, W. J. (1996). Protein requirements of elderly people. European Journal of Clinical Nutrition 50, Suppl. 1, S180-S185 
Castaneda, C., Charnley, J. M., Evans, W. J. \& Crim, M. C. (1995). Elderly women accommodate to a lowprotein diet with losses of body cell mass, muscle function, and immune response. American Journal of Clinical Nutrition 62, 30-39.

Cheng, A. H. R., Gomez, A., Bergan, J. G., Lee, T.-C., Monckeberg, F. \& Chichester, C. O. (1978). Comparative nitrogen balance study between young and aged adults using three levels of protein intake from a combination wheat-soy-milk mixture. American Journal of Clinical Nutrition 31, $12-22$.

Cohn, S. H., Vartsky, D., Yasumura, S., Sawitsky, A., Zanzi, I., Vaswani, A. \& Ellis, K. J. (1980). Compartmental body composition based on total-body nitrogen, potassium, and calcium. American Journal of Physiology 239, E524-E530.

Coyer, P. A., Rivers, J. P. W. \& Millward, D. J. (1987). The effect of dietary protein and energy restriction on heat production and growth costs in the young rat. British Journal of Nutrition 58, 73-85.

Crim, M. C. \& Munro, H. N. (1994). Proteins and amino acids. In Modern Nutrition in Health and Disease, 8th edn, vol. 1, pp. 3-35 [A. E. Shils, J. A. Olsen and M. Shike, editors]. Philadelphia, PA: Lea \& Febiger.

Department of Health (1991). Dietary Reference Values for Food Energy and Nutrients of the United Kingdom. London: HMSO.

Durkin, N., Ogar, D. A., Tilve, S. G. \& Margen, S. (1984). Human protein requirements: autocorrelation and adaptation to a low-protein diet. In Protein-Energy-Requirement Studies in Developing Countries: Results of International Research (Food and Nutrition Bulletin, Suppl. 10) pp. 57-62 [W. M. Rand, R. Uauy and N. S. Scrimshaw, editors].

Egun, G. N. \& Atinmo, T. (1993). Protein requirement of young adult Nigerian females on habitual Nigerian diet at the usual level of energy intake. British Journal of Nutrition 70, 439-448.

Evans, W. J. \& Campbell, W. W. (1993). Sarcopenia and age-related changes in body composition and functional capacity. Journal of Nutrition 123, 465-468.

FAO/WHO (1973). Energy and Protein Requirements (Technical Report Series no. 522). Geneva: World Health Organization.

FAO/WHO/UNU (1985). Energy and Protein Requirements (Technical Report Series no. 724). Geneva: World Health Organization.

Garza, C., Scrimshaw, N. S. \& Young, V. R. (1976). Human protein requirements: the effect of variations in energy intake within the maintenance range. American Journal of Clinical Nutrition 29, 280-287.

Gersovitz, M., Motil, K., Munro, H. N., Scrimshaw, N. S. \& Young, V. R. (1982). Human protein requirements: assessment of the adequacy of the current Recommended Dietary Allowance for dietary protein in elderly men and women. American Journal of Clinical Nutrition 35, 6-14.

Hegsted, D. M. (1976). Balance studies. Journal of Nutrition 106, 307-311

Hill, G. L. (1994). Impact of nutritional support on the clinical outcome of the surgical patient. Clinical Nutrition 13, 331-340.

Millward, D. J. (1995). A protein-stat mechanism for regulation of growth and maintenance of the lean body mass. Nutrition Research Reviews 8, 93-120.

Millward, D. J., Jackson, A. A., Price, G. \& Rivers, J. P. W. (1989). Human amino acid and protein requirements: current dilemmas and uncertainties. Nutrition Research Reviews 2, 109-132.

Munro, H. N., McGandy, R. B., Hartz, S. C., Russell, R. M., Jacob, R. A. \& Otradovec, C. L. (1987). Protein nutriture of a group of free-living elderly. American Journal of Clinical Nutrition 46, 586-592.

National Research Council (1989). Recommended Dietary Allowances, 10th edn. Washington, DC: National Academy Press.

Pannemans, D. L. E., Halliday, D. \& Westerterp, K. R. (1995a). Whole-body protein turnover in elderly men and women: responses to two protein intakes. American Journal of Clinical Nutrition 61, 33-38.

Pannemans, D. L. E., Halliday, D., Westerterp, K. R. \& Kester, A. D. M. (1995b). Effect of variable protein intake on whole-body protein turnover in young men and women. American Journal of Clinical Nutrition 61 , 69-74.

Pellett, P. L. \& Young, V. R. (1992). The effects of different levels of energy intake on protein metabolism and of different levels of protein intake on energy metabolism: a statistical evaluation from the published literature. In Protein-Energy Interactions, pp. 81-122 [N. S. Scrimshaw and B. Schurch, editors]. Lausanne, Switzerland: International Dietary Energy Consultative Group.

Price, G. M. (1991). Nitrogen Homeostasis In Man. PhD thesis, University of London.

Price, G. M., Halliday, D., Pacy, P. J., Quevedo, M. R. \& Millward, D. J. (1994). Nitrogen homeostasis in man. 1. Influence of protein intake on the amplitude of diurnal cycling of body nitrogen. Clinical Science 86, 91-102.

Quevedo, M. R., Price, G. M., Halliday, D., Pacy, P. J. \& Millward, D. J. (1994). Nitrogen homeostasis in man. 3. Diurnal changes in nitrogen excretion, leucine oxidation and whole body leucine kinetics during a reduction from a high to a moderate protein intake. Clinical Science 86, 185-193.

Rand, W. M., Scrimshaw, N.S. \& Young, V. R. (1981). Conventional long term nitrogen balance studies for protein quality evaluation in adults: rationale and limitations. In Protein Quality in Humans: Assessment and In vitro Estimation, pp. 59-97 [C. E. Bodwell, J. S. Atkins and D. T. Hopkins, editors]. Westport, CT: AVI.

Rand, W. M., Scrimshaw, N. S. \& Young, V. R. (1985). Retrospective analysis of data from five long-term, metabolic balance studies: implications for understanding dietary nitrogen and energy utilization. American Journal of Clinical Nutrition 42, 1339-1350. 
Rand, W. M., Young, V. R. \& Scrimshaw, N. S. (1976). Change of urinary nitrogen excretion in response to lowprotein diets in adults. American Journal of Clinical Nutrition 29, 639-644.

Roberts, S. B. (1996). Energy requirements of older individuals. European Journal of Clinical Nutrition 50, Suppl. 1, S112-S118.

Rosenberg, I. H. (1989). Epidemiologic and methodologic problems in determining nutritional status of older persons. Summary comments. American Journal of Clinical Nutrition 50, 1231-1233.

Scrimshaw, N. S., Hussein, M. A., Murray, E., Rand, W. M. \& Young, V. R. (1972). Protein requirements of man: variations in obligatory urinary and fecal nitrogen losses in young men. Journal of Nutrition 102 , $1595-1604$

Scrimshaw, N. S., Perera, D. A. \& Young, V. R. (1976). Protein requirements of man: obligatory urinary and fecal nitrogen losses in elderly women. Journal of Nutrition 106, 665-670.

Sukhatme, P. V. \& Margen, S. (1978). Models for protein deficiency. American Journal of Clinical Nutrition 31, $1237-1256$

Thorogood, M. (1995). The epidemiology of vegetarianism and health. Nutrition Research Reviews 8, $179-192$.

Uauy, R., Scrimshaw, N. \& Young, V. (1978). Human protein requirements: nitrogen balance response to graded levels of egg protein in elderly men and women. American Journal of Clinical Nutrition 31, 779-785.

UNU/WHP (1979). Protein-energy requirements under conditions prevailing in developing countries: current knowledge and research needs. Food and Nutrition Bulletin Suppl. 1.

Waterlow, J. C. (1990). Nutritional adaptation in man: general introduction and concepts. American Journal of Clinical Nutrition 51, 259-263.

Young, V. R. (1986). Nutritional balance studies: indicators of human requirements or of adaptive mechanisms? Journal of Nutrition 116, 700-703.

Young, V. R., Gucalp, C., Rand, W. M., Matthews, D. E. \& Bier, D. M. (1987). Leucine kinetics during three weeks at submaintenance-to-maintenance intakes of leucine in men: adaptation and accommodation Human Nutrition: Clinical Nutrition 41C, 1-18.

Young, V. R., Taylor, Y. S. M., Rand, W. M.\& Scrimshaw, N. S. (1973). Protein requirements of man: efficiency of egg protein utilization at maintenance and submaintenance levels in young men. Journal of Nutrition 103, $1164-1174$

Zanni, E., Calloway, D. H.\& Zezulka, A. Y. (1979). Protein requirements of elderly men. Journal of Nutrition 109, 513-524. 